\title{
An Empirical Study of the Influence of Multimedia on Primary School English Teaching Based on Situated Cognition Theory -A Case Study of Nanyuan Central Primary School
}

\author{
QI Jia-yu \\ Ningbo Dahongying University, Ningbo, China
}

\begin{abstract}
According to the cognition theory, knowledge is contextualized and develops through constant activities so that it is essential to create an appropriate learning situation to encourage students to learn in real situations. Situated Cognition Theory equally emphasizes that learners should be the main body in the design of learning, the arrangement of the content and activities should be associated with the concrete practice of human society. Teachers should organize activities of class teaching that are similar to real human practice, at best in the real situation, meantime, mingle the acquisition of knowledge and the development of learners as well as the identity construction. Based on Situated Cognition Theory, this paper uses questionnaire survey, takes as subjects 100 pupils from Grade 4 to Grade 5 of Nanyuan Central Primary School in Yuhang District, explores the positive and negative influences of multimedia teaching during the process of English teaching in primary schools, and appropriate countermeasures to get rid of the negative influence and to help not only teachers to improve their class teaching by multimedia use but also pupils to improve their levels of English learning.
\end{abstract}

Keywords: Situated Cognition Theory, multimedia, class teaching

\section{Introduction}

With the accelerated development of economic globalization, English plays a more important role in communication and becomes an indispensable tool for communication in various aspects of society, economy, and culture. English is so widely used in our daily life that it is necessary to take reasonable and effective teaching methods in primary school English teaching. Under the New National English Curriculum Standards, students should be given chances not only to contact with a lot of real and authentic English but also to use it; on the other hand, multimedia creates a good learning environment for pupils, in which they can listen, speak, read, and write. Compared with the traditional English teaching mode, multimedia abandons some boring contents in textbooks reasonably, creates a relatively realistic vivid learning environment for pupils so that many English teachers in primary schools prefer multimedia as it can fully show the relaxed and pleasant features of English class in primary schools. However, the deficiencies of multimedia cannot be ignored in teaching; based on this, the paper analyzes problems in multimedia use in primary school English teaching and explores appropriate

QI Jia-yu, undergraduate, College of Humanities, Ningbo Dahongying University. 
countermeasures by using questionnaire survey based on Situated Cognition Theory, with the hope of helping teachers to enhance their teaching quality and pupils to improve their levels of English learning.

\section{Literature Review}

Currently, multimedia is extensively used in class teaching in schools of all levels, whose use is helpful to eliminate English class boredom to a certain degree. As to the new teaching mode, many foreign scholars have their own views. M. Krashen (1985) holds that multimedia mingles texts, images, voices, and videos, which help have an effective output to the utmost and it can create to the maximum the culture situation about the country dominated by target language so that learners are put in a virtual but relatively real language environment. Noel Watts (1997) points out that interactive multimedia teaching has a great potential. Levy (2000) thinks that technology (i.e., multimedia) is to influence the ultimate targets of learners, the nature of the learning environment, the teachers' own education, etc. The above foreign researchers propose different opinions about multimedia, which stress that learning is realized in the establishment of the relative real learning environment, thus helping overcome the deficiencies of multimedia and enhancing the effectiveness of primary school English teaching.

In addition, domestic scholars' researchers hold various views about the influences of multimedia on primary school teaching. YANG Chun-hui (2000) summaries characteristics of multimedia: the individualized learning environment; explorative learning; the combination of image and text, timely feedback, high learning efficiency as well as the student-centered class teaching. WEI song (2007) points out that multimedia can improve students' ability of speaking English. For one thing, multimedia provides sufficient learning resources for students; for another, it can create such a relatively interesting language learning environment for students that they are more willing to learn in the environment. DI Li-fang (2010) deems that it enhances the effectiveness of English class teaching to the maximum by providing the situation similar to real life, thus attracting more students to participate in teaching activities to increases their interest in English learning. HAN Yan (2008) pinpoints defects of multimedia: That is, it is so easy to formalize and template that it may cause teachers to instill too much knowledge into students' minds without considering if they can comprehend and accept. The above Chinese researchers put forward their views on multimedia in teaching and pay attention to students' learning situation and the effectiveness of teaching, and summarize the influences of the multimedia teaching on class teaching in primary school English.

This paper, based on the perspective of Situated Cognition Theory, explores the influences of multimedia on class teaching in primary school English, analyzes its deficiencies in teaching to use multimedia more effectively, promote primary school English teaching, and improve students' ability of English learning.

\section{Situated Cognition Theory}

Situated Cognition Theory argues that knowledge exists in the actions of groups and individuals and knowledge is generated as individuals participate and negotiate mutually in new situations. The development of knowledge and ability is the same as language, both of which occur in the actual situation and the activities of using knowledge continuously. The authenticity of the class situation means that the situation teachers establish need correspond to the real social situation, the life situation, and the situation of research activities. According to 
the theory, knowledge is contextualized and develops constantly through activities so that participating in practice promotes students to learn in relatively real situations, which is essential to create appropriate learning situations.

\section{Research Methodology}

This research takes as subjects pupils in Grade 4 and Grade 5 Nanyuan Central Primary School in Yuhang District and adopts questionnaire survey to find out the current situation of multimedia use in primary school English teaching. The research is composed of four parts, which are subjects, instrument, procedures, data collection, and results.

\section{Subjects}

In the research, 100 pupils from Yuhang District Nanyuan Central Primary School, who are in Grade 4 and Grade 5. They have more clear ideas about English learning and a great potential for the development of cognitive ability. These pupils in the primary school are selected so that the empirical study is made more reliable and persuasive.

\section{Instrument}

The research method applied in this research is questionnaire, which consists of 20 questions, each of which has four or five options; different choices reflect whether pupils accept multimedia in class teaching and whether teachers perform well in English teaching based on Situated Cognition Theory.

\section{Procedures}

In order to ensure the validity and reliability of the research, pupils are supposed to fill out the questionnaire. 100 students are selected randomly from Grade 4 and Grade 5 and 100 valid questionnaires are collected. All the data of the questionnaire are collected and analyzed, and have a comparison with the help of Excel.

\section{Data Collection and Results}

The data is collected from pupils in Grade 4 and Grade 5. The 100 questionnaire collected from these pupils prove effective. And the following are the results of the research. Based on the questionnaire, it concludes that the pupils all think that multimedia is helpful to raise their interest in English learning, especially in Grade 4. Over 60 percent choose the "Easy" in distracting attention, which reflects that in using multimedia, pupils tend to distract their attention easily. "Whether teachers have much interaction with pupils in class", 50 percent of pupils in Grade 5 choose "Not enough", which indicates that teachers omit the interaction with students. As to "Whether multimedia is helpful for pupils to improve learning and memory", more than 50 percent of pupils in Grade 4 choose "helpful", which reflects that multimedia is useful to improve learning and memory. Though teachers think that using multimedia helps create a more effective environment, it cannot be denied that preparing an appropriate courseware is a difficult task. 
Table 1

Positive Influences of Multimedia on Primary School English Teaching

\begin{tabular}{|c|c|c|c|c|c|}
\hline \multirow{2}{*}{ Grade } & & \multicolumn{2}{|c|}{ Grade 4} & \multicolumn{2}{|c|}{ Grade 5} \\
\hline & & Number & Percentage & Number & Percentage \\
\hline \multirow{3}{*}{$\begin{array}{l}\text { Whether multimedia is helpful for } \\
\text { pupils to raise interest in learning } \\
\text { English }\end{array}$} & Helpful & 35 & $70 \%$ & 30 & $60 \%$ \\
\hline & Average & 13 & $26 \%$ & 15 & $30 \%$ \\
\hline & Not helpful & 2 & $4 \%$ & 5 & $10 \%$ \\
\hline \multirow{3}{*}{$\begin{array}{l}\text { Whether it is helpful for pupils to } \\
\text { improve learning and memory }\end{array}$} & Helpful & 28 & $56 \%$ & 25 & $50 \%$ \\
\hline & Average & 13 & $26 \%$ & 15 & $30 \%$ \\
\hline & Not helpful & 9 & $18 \%$ & 10 & $20 \%$ \\
\hline \multirow{3}{*}{$\begin{array}{l}\text { Whether it is helpful for teachers to } \\
\text { create a more effective environment }\end{array}$} & Helpful & 34 & $68 \%$ & 27 & $54 \%$ \\
\hline & Average & 13 & $26 \%$ & 18 & $36 \%$ \\
\hline & Not helpful & 3 & $6 \%$ & 5 & $10 \%$ \\
\hline
\end{tabular}

Table 2

Negative Influences of Multimedia on Primary School English Teaching

\begin{tabular}{llllll}
\hline \multirow{2}{*}{ Grade } & & \multicolumn{2}{c}{ Grade 4} & \multicolumn{2}{c}{ Grade 5 } \\
\cline { 3 - 5 } & & Number & Percentage & Number & Percentage \\
\hline \multirow{2}{*}{$\begin{array}{l}\text { Whether the courseware materials } \\
\text { teachers prepare are appropriate }\end{array}$} & Appropriate & 20 & $40 \%$ & 22 & $44 \%$ \\
& Average & 13 & $26 \%$ & 8 & $16 \%$ \\
\hline \multirow{2}{*}{$\begin{array}{l}\text { Whether teachers have much } \\
\text { interaction with pupils in class }\end{array}$} & Not appropriate & 17 & $34 \%$ & 20 & $40 \%$ \\
\hline \multirow{2}{*}{$\begin{array}{l}\text { Whether it is easy for pupils to distract } \\
\text { attention in learning English }\end{array}$} & Evough & 17 & $34 \%$ & 9 & $18 \%$ \\
& Not enough & 13 & $26 \%$ & 16 & $32 \%$ \\
& Average & 20 & $40 \%$ & 25 & $50 \%$ \\
\hline
\end{tabular}

\section{Findings}

Through the analysis of the research results, it is concluded that multimedia has a large impact on primary school English teaching, which contains positive influence and negative influence, and the latter is so representative that it is necessary to analyze it. The following is the detailed analysis on the influences of multimedia on primary school English teaching.

\section{Positive Influence of Multimedia on Primary School English Teaching}

Multimedia has a positive influence on English teaching in primary school, which is presented in three aspects as is seen in Table 1 .

Being helpful to raise pupils' interest in English learning. Psychologists believe that interest is a psychological tendency and a positive emotional experience. Multimedia can greatly improve students' interest in English learning and stimulate their enthusiasm for it. Piaget (1982) points out that interest can influence all the work in human intelligence. In the traditional English class, pupils always read English sentences repeatedly and mechanically, recite words over and over so that they are unwilling to attend English classes. However, compared with the traditional class, multimedia cannot singly mingle texts, sounds, and images but provide various visual materials for pupils. It overcomes the deficiencies of traditional English teaching and attracts 
pupils' attention through bright colors, fair-sounding music, interesting animation, and rich contents, thereby improving the effectiveness of class teaching.

Being useful to improve learning and memory. People can obtain memory through many ways but the success rates of vision and audition are far higher than the other senses. According to a survey of the French audiovisual education, students can only remember $15 \%$ of information by listening and they may remember $25 \%$ by seeing; however, audio-visual combination can help them remember more than $65 \%$. Therefore, the dynamic demonstration of multimedia courseware helps create a vivid learning situation, in which words, phrases, sentences, and dialogues shown to pupils intuitively, vividly, and conveniently, thus arousing their interest in English, improving their learning and memory as well as the effectiveness of class teaching.

Being conducive to creating a more effective classroom environment. In English teaching, multimedia can create a more effective class environment for learning English, whose courseware may show a great many pictures and videos similar to a relatively real situation, which corresponds to the dialogue, so that pupils have a better feeling about the content and the emotion, thus enabling them to focus their attention and partake in learning English more actively. Meanwhile, teachers get their courseware ready before class to add some extra curricular contents based on the actual situation, thus enriching pupils' knowledge and strengthening their memory and comprehension of it.

\section{Negative Influence of Multimedia on Primary School English Teaching}

In addition to the positive influence, the negative influence of multimedia cannot be ignored, which are presented in three perspectives as is seen in Table 2.

Preparing inappropriate and time-consuming courseware materials. Making a courseware mainly depends on teachers themselves. However, it is such a heavy task for which they have to spend much time and energy so that the Internet becomes the main way for teachers to prepare their courseware or some teachers directly use the CDs attached to textbooks. Such a courseware tends to be inappropriate and difficult to achieve the expected results. Moreover, making a courseware both teachers and pupils satisfied is very complex; only a few teachers equipped with rich teaching experience, computer skills and many network materials can finish preparing a courseware in a relatively short period of time. In such cases, it is not difficult to find that courseware making is a time-consuming task.

Distracting pupils' attention. In order to meet pupils' visual and auditory needs, stimulate their interest, and create an active classroom atmosphere, many teachers, in their courseware, use too many sounds, images, words and other information, thus distracting the attention of pupils and affecting the realization of the teaching goal. The reason for it is that teachers put all the teaching objectives, focuses, difficulties, learning methods, as well as teaching materials into only one courseware so that pupils do not have a close look at the content or see the content but without thinking before teachers start the next content, thus leading to the unsatisfactory effectiveness of class teaching.

Decreasing the interaction between pupils and teachers. Multimedia is easy to dilute the interaction between teachers and students. With more use of multimedia teaching, the amount of teaching information increases significantly. Sometimes in order to guarantee the progress of teaching, teachers may accelerate their teaching so unconsciously that pupils' thinking cannot catch up with teaching. In class teaching, teachers keep 
operating the mouse, neglect pupils' performance in class, while most of them only focus on the screen, without paying much attention to what teachers say, thus reducing the interaction between teachers and pupils.

\section{Countermeasures and Implication}

Based on Situated Cognition Theory, it is necessary for teachers to minimize the negative influence of multimedia courseware, so that multimedia can be used more effectively in primary school English class.

\section{Exertion of Positive Role of Multimedia Based on Situated Cognition Theory}

In using multimedia in primary school English class, teachers can give full play to the positive influence of multimedia based on Situated Cognition Theory.

Improving teachers' ability of teaching and making courseware. Teachers are expected to master skills of making courseware to spend their less time and energy on it, which is the most basic requirement for the quality of teachers. In order to create a right learning environment in English class, teachers need to adopt appropriate courseware contents by following new educational theories and updating educational concepts constantly. Making courseware needs well-prepared software, orderly-managed data; it also demands to put lesson planning before making courseware, to decide courseware focuses, to pay more attention to teaching strategies, and to keep the proper capacity of courseware.

Choosing appropriate teaching media. Levy (2000) thinks that it is necessary for teachers to draw on the positive influence of technology, to give students positive learning experiences and to minimize the negative factors as far as possible. The presentation of multimedia mingles sounds and images, thus creating a relatively realistic learning environment for pupils. However, it is so easy to formalize that pupils cannot focus their attention in class for a long time. Therefore, teachers need select the appropriate courseware to conduct class teaching on the basis of different levels of pupils, teaching objectives, and contents.

Grasping the best display point and the best time for action. Multimedia can integrate teaching contents perfectly in class through sounds, images, and colors to form a memorable audio-visual effect and to create a suitable learning environment for pupils, while they find it so difficult to reject distraction because of multimedia that they cannot think and solve problems actively. Hence, teachers are required to attach great importance to combining multimedia with other teaching methods and to grasp points and moments of the best display of the courseware whose contents are based on the circumstances closer to pupils' life in order to fully play a positive role of multimedia, thereby cultivating pupils' interest in English learning and improving their ability of listening and speaking as well as the effectiveness of class teaching.

Paying attention to strengthen teachers' guiding role. Teachers should utilize multimedia to encourage pupils to cultivate the spirit of exploration and solve problems on their own without imparting knowledge into their minds as the primary goal of teaching so that they should pay attention to not merely playing their guiding role in the teaching process of using multimedia but also giving full play to the main role of pupils. On the other hand, teachers should change their concepts of education and strive to improve their teaching constantly by mastering skills of multimedia.

\section{Implication}

Based on Situated Cognitive Theory, this paper analyzes the positive influence of multimedia in primary 
school English teaching from four aspects and proposes that teachers should give full play to the positive influence of multimedia and avoid its negative influence as much as possible in primary school English teaching in order to help it develop in the right direction, to develop pupils' interest in English learning and enhance their ability of listening and speaking as well as the effectiveness of class teaching.

\section{Conclusion}

This paper takes as subjects 50 pupils in Grade 4 and 50 pupils in Grade 5 in Nanyuan Central Primary School in Yuhang District in the form of questionnaire survey based on Situated Cognition Theory to explore the positive and negative influences of multimedia in primary school English teaching as well as suitable countermeasures in order to help teachers to minimize the negative influence of multimedia and to maximize the positive one based on the theory. The positive influence is explored from three aspects of help in improving pupils' interest in English learning, usefulness in improving their learning and memory, and assistance in creating a more effective classroom environment; the negative influence includes much time spent in making courseware, the content of courseware unsuitable for pupils, distraction of their attention, and the decrease in the interaction between teachers and pupils. Accordingly, four countermeasures are proposed based on Situated Cognition Theory to dramatically reduce the negative influence of multimedia and significantly increase the positive influence. Although this research has some limits, it can be used to some degree to help not simply pupils to learn English more easily but teachers to better conduct English teaching.

\section{References}

DI, L. F. (2010). On the application of multimedia educational technology to primary school English classes. Youth Literator, 20, 53.

HAN, Y. (2008). An analysis of the advantages and disadvantages of using multimedia in class teaching. Shanxi Education: Teacher's Teaching, 5, 30.

Krashen, M. (1985). Second language acquisition and second language learning. Understanding Second Language Learning Acquisition, 12, 84-89.

Levy, M. S. (2002). Scope, goals and methods in CALL research questions of coherence and autonomy. RECALL, 12(2), $170-195$.

Piaget, J. (1982). Educational science and child psychology. Beijing: Cultural Education Press.

Watt, N. (1997). A learner-based design model for interactive multimedia language learning packages. System, 25(96), 1-8.

WEI, S. (2007). A research on some key issues in human-machine dialogue system (Unpublished doctoral dissertation, Beijing University of Posts and Telecommunications, Beijing).

YANH, C. H. (2000). A tentative discussion on characteristics of multimedia-aided English teaching. Computer-Assisted Foreign Language Education, 1, 46-47. 